PROCEDIA

Studi Kasus dan Intervensi Psikologi

ISSN:2302-1462

Volume 7(2) 55-64, Januari 2019

DOI: $10.22219 /$ procedia.v7i2.13023

\title{
Self-control untuk mengurangi perilaku menonton film dewasa di internet
}

Elis Suci Prapita Sari Abdullah, Universitas Muhammadiyah Malang, Malang, Indonesia

Korespondonesi:

Elis Suci Prapita Sari Abdullah, Universitas Muhammadiyah Malang, Malang,

email: elissuci9@gmail.com

Riwayat artikel
Naskah diterima:
02/03/2019
Revisi diterima:
29/04/2019
Naskah disetujui:
24/05/2019

\begin{abstract}
Abstrak
AH (laki-laki/26 tahun) mengalami suatu permasalahan yaitu kesulitan dalam mengontrol perilaku maladaptif berupa menonton film dewasa beradegan porno di internet. Berdasarkan hasil asesmen menggunakan berbagai metode asesmen seperti wawancara, tes WAIS, dan instrumen berupa cyber pornography addiction test (CYPAT). Subjek kurang mampu dalam mengontrol dirinya untuk melakukan perilaku menonton film dewasa di internet. Hal tersebut dikarenakan adanya kepuasan dan perasaan nyaman yang dialami subjek setelah melakukan perilaku tersebut. Namun, di sisi lain subjek juga merasa dirugikan karena produktivitas kesehariannya menjadi menurun akibat terlalu banyak waktu yang dihabiskan untuk menonton. Intervensi bertujuan untuk mengontrol diri agar terhindar dari situasi pemicu yang dapat membuat subjek melakukan aktivitas menonton film dewasa di internet. Hasil intervensi menunjukkan bahwa subjek menunjukkan pencapaian yang cukup baik dalam mengontrol perilakunya. Intensitas perilaku maladaptif berupa menonton film dewasa beradegan porno menjadi berkurang.

Kata kunci: Self control, excessive behavior, cyber pornography addiction, terapi perilaku
\end{abstract}

\section{Latar Belakang}

Kecanduan internet biasa disebut dengan penggunaan internet yang berlebihan atau bermasalah, yang mencakup perilaku tertentu berupa penggunaan media sosial, game, pornografi, serta kecanduan internet lainnya secara umum (Block, 2008). Kecanduan pornografi di internet biasanya melibatkan perilaku menonton, mengunduh, dan memperdagangkan pornografi secara kompulsif, atau terlibat dalam permainan peran fantasi orang dewasa, yang umumnya 
dikaitkan dengan isolasi antarpribadi, respon terhadap suasana hati yang buruk atau stres, dan masalah relasional (Cacioppo et al., 2018). Menonton pornografi secara berlebihan dapat dikonseptualisasikan sebagai kecanduan perilaku (Kraus, Martino, \& Potenza, 2016).

Orang-orang yang melihat pornografi secara berlebihan mengalami kesulitas dalam mengontrol penggunaannya, munculnya desakan atau dorongan yang kuat, mengalami gangguan sosial-pekerjaan, atau penggunaan pornografi untuk mengatasi kecemasan (Kraus, Rosenberg, Martino, Nich, \& Potenza, 2017). Para peneliti telah mengidentifikasi beberapa aspek negatif yang dapat dikaitkan dengan kecanduan pornografi internet, seperti menghabiskan terlalu banyak waktu untuk mencari materi pornografi atau merasa bersalah setelah menonton materi pornografi (Spenhoff, Kruger, Hartmann, \& Kobs, 2013). Adapun situasi-situasi yang memunculkan dorongan dalam penggunaan pornografi adalah ketika merasa terangsang secara seksual, sendirian di rumah, saat menggunakan internet, mengalami kesedihan, kebosanan, atau stress.

Penggunaan pornografi internet secara berlebihan juga dikaitkan dengan disfungsi keluarga, konsekuensi hukum, isolasi diri, dan tekanan psikologis. Tingkat penggunaan yang tinggi sangat mungkin dapat menimbulkan konsekuensi negatif, seperti mengganggu fungsi pribadi, pekerjaan, atau hubungan sosial (Grubbs, Volk, Exline, \& Kenneth, 2014). Kondisi tersebut terjadi pada subjek dimana dirinya merasa lega dan nyaman ketika mengalihkan aktivitasnya pada perilaku menonton film dewasa saat ia merasa bosan dan jenuh dengan aktivitasnya. Ada efek tertentu yang membuat subjek menjadi mengulang-ulang perilaku maladaptif tersebut. Namun, di sisi lain ia merasa dirugikan oleh adanya perilaku tersebut. Subjek juga merasa bahwa perilakunya tersebut sudah bermasalah dikarenakan alasan moral atau agama, serta terhambatnya produktivitas keseharian subjek.

Dengan melihat dampak yang dirasakan dan kerugian yang dialami oleh subjek, maka diperlukan adanya suatu bentuk penanganan yang bisa membantu subjek untuk mengurangi perilaku maladaptif yang sedang dialaminya. Hal tersebut juga didukung oleh keinginan subjek untuk mengurangi bahkan menghilangkan perilaku menonton film dewasa beradegan porno yang seringkali ia lakukan. Dalam hal ini, intervensi menggunakan modifikasi perilaku dengan metode self control dinilai efektif untuk membantu subjek dalam mencapai target perilaku yang diinginkan. Metode ini bisa digunakan untuk mengurangi perilaku berlebihan, dimana diperlukan peningkatan pengetahuan mengenai teknik dalam mengubah perilaku yang akan digunakan dan komitmen untuk berubah dari subjek.

\section{Metode Asesmen}

Asesmen yang telah dilakukan untuk penegakan diagnosa melalui serangkaian metode antara lain wawancara dan tes psikologi. Wawancara dilakukan dengan subjek untuk memperoleh informasi lebih mendalam tentang riwayat keluhan yang dimiliki subjek, khususnya perilaku maladaptif yang dilakukan oleh subjek. Tes intelegensi menggunakan Weschler Adult Intelligence Scale (WAIS) untuk mengetahui kapasitas intelektual, kemampuan dalam pengambilan keputusan dan pemecahan masalah, serta pemahaman dan ketertarikan subjek dalam hubungan sosial. Tes grafis digunakan untuk melihat gambaran kepribadian subjek dan kerentanan psikologis yang dimiliki. SSCT digunakan untuk melihat gambaran hubungan subjek dengan berbagai komponen di kehidupannya. Instrumen yang digunakan berupa Cyber Pornography Addiction Test (CYPAT) untuk mengukur tingkat kecanduan pornografi di internet yang dialami oleh subjek.

\section{Presentasi Kasus}

Subjek (laki-laki) berusia 26 tahun, anak pertama dari dua bersaudara, ia tinggal bersama ibu dan saudaranya. Ayah subjek telah meninggal saat subjek berada di kelas VII SMP. Subjek 
menjelaskan bahwa ayahnya cenderung mengasuhnya dengan cara yang keras, sementara ibunya cukup baik dan sabar dalam memenuhi kebutuhan anak-anaknya. Hal tersebut juga terlihat dari hasil SSCT bahwa subjek menilai negatif terhadap peran ayah dan menilai positif terhadap peran ibu dalam kehidupannya. Namun, secara keseluruhan subjek merasa bahwa ia kurang mendapatkan kasih sayang dari orang tuanya.

Saat ini subjek mengeluhkan bahwa dirinya memiliki suatu permasalahan yang mengganggu dalam dirinya, yaitu kecenderungan melakukan perilaku maladaptif berupa menonton film dewasa di internet. Intensitas ia melakukan aktivitas tersebut adalah 4-5 kali seminggu dengan frekuensi 3-4 jam, selanjutnya efek yang dirasakan adalah ia menjadi malas untuk melanjutkan aktivitas kesehariannya seperti bekerja.

Perilaku menonton film dewasa di internet yang dilakukan subjek berawal dari rasa penasaran subjek setelah melihat foto-foto orang dewasa yang ada di koran ketika ia masih SMP. Selain itu, subjek adalah seorang yang pendiam dan tertutup sehingga semasa sekolah ia sering diejek dan dijauhi oleh teman-temannya. Kondisi tersebut yang membuat subjek merasa sendiri dan tidak nyaman, sehingga ketika ia melihat film dewasa di internet ia menjadi lebih lega dan munculnya kepuasan tertentu setelah menonton. Tentunya tidak ada orang lain yang mengetahui bahwa subjek menyukai menonton pornografi di internet. Hal tersebut dikarenakan ia cenderung menutup diri dan malu jika orang lain mengetahui kebiasaan buruknya tersebut.

Kondisi terparah subjek untuk terlibat dalam aktivitas tersebut adalah saat SMA hingga ia berusia 20-an tahun. Intensitas terbilang sering dengan frekuensi yang sangat lama subjek menghabiskan waktu hanya untuk melakukan aktivitas tersebut. Subjek merasakan kepuasan tertentu dan lega setelah menonton dan akan merasa gelisah ketika ia tidak menonton dalam sehari, hal itulah yang membuat subjek melakukan perilaku tersebut secara berulang-ulang. Hingga saat ini, subjek masih kurang mampu untuk menahan dorongan dalam dirinya untuk melihat pornografi di internet. Namun, beberapa bulan terakhir ini subjek telah berusaha untuk mengontrol dirinya yang menghasilkan perubahan intensitas yang hampir setiap hari menjadi 4-5 kali per minggu.

Adapun situasi-situasi yang memunculkan keinginan subjek untuk melakukan aktivitas tersebut adalah ketika sendiri, tidak ada aktivitas atau banyaknya waktu luang, melakukan streaming di smartphone, dan melihat perempuan yang berpakaian seksi. Ketika keinginan muncul, ia merasa gelisah dan tidak nyaman sehingga ia harus melakukan aktivitas tersebut. Tentunya efek dari aktivitas tersebut membuat subjek merasa lega dan tenang. Di samping itu, saat ini subjek menyadari bahwa aktivitas tersebut membawa efek negatif yang mempengaruhi kehidupannya, yaitu ia menjadi malas untuk melanjutkan aktivitas setelah menonton, mengganggu konsentrasi, menurunnya kemampuan otak dalam menyerap informasi, mudah lupa, mengganggu produktivitas sehari-hari, dan adanya perasaan berdosa. Hal tersebut yang membuat subjek sangat ingin mengurangi bahkan menghilangkan kebiasannya dalam menonton pornografi di internet.

Keinginan subjek untuk mengurangi bahkan menghilangkan perilaku tersebut telah membawa subjek pada usaha-usaha yang dilakukannya. Usaha-usaha tersebut berupa mencari banyak aktivitas di luar rumah selain bekerja, seperti mengikuti pelatihan untuk menambah keterampilan dan pengajian di masjid, serta melakukan aktivitas olahraga. Namun, hal tersebut terkendala dengan aktivitas subjek dalam memakai smartphone. Selain itu, ia menilai bahwa usaha tersebut justru menjadikan subjek merasa tersiksa karena harus menahan keinginannya untuk menonton video dan film dewasa di internet. Dalam hal ini, subjek hanya perlu melakukan kontrol terhadap dirinya dengan konsisten dan beradaptasi dengan perasaan tidak nyaman yang ia rasakan ketika ingin mengubah perilaku maladaptif yang ia lakukan. Serta adanya dukungan dari orang lain yang memandang perilakunya tersebut secara lebih objektif. 
Hasil SSCT menunjukkan bahwa subjek merasa bahwa terlalu banyak waktu yang ia sia-siakan dan ia tidak menghargai waktunya dengan baik, sehingga ia menyesal dan sangat menginginkan untuk memperbaiki dirinya dan mengubah kebiasaan buruknya. Tidak ada orang lain yang mengetahui tentang kondisi dirinya saat ini, karena ia takut jika orang lain mengetahui justru akan memperburuk kondisinya. Subjek menyadari bahwa apa yang dilakukannya selama ini adalah sesuatu hal yang salah dan melanggar hukum. Pernyataan-pernyataan tersebut merupakan hasil proyeksi dari subjek terhadap perilaku yang ia keluhkan saat ini yaitu perilaku maladaptif berupa menonton pornografi di internet.

Hasil WAIS menunjukkan bahwa kapasitas kecerdasan yang dimiliki subjek menunjukkan skor sebesar 89 termasuk dalam kategori adalah low average. Subjek memiliki kemampuan dalam melakukan penyesuaian terhadap masalah sosial hingga pada membuat planning, interpretasi, dan pemecahan masalah. Subjek mampu dalam memahami situasi sosial dan mengevaluasi implikasinya, yang didukung oleh adanya gagasan dan pengembangan bahasa yang baik pada subjek. Namun, di sisi lain subjek kurang mampu dalam melakukan penyesuaian diri di lingkungan sosial dan kurang mampu dalam menghadapi situasi-situasi emosional yang membuatnya kesulitan dalam mengambil keputusan.

Hasil tes grafis menunjukkan bahwa subjek memiliki kepribadian yang introvert, pendiam, dan tertutup. Subjek cenderung impulsif dan membiarkan dorongan-dorongan yang tidak cermat untuk mencapai suatu kepuasan, ditambah lagi dengan kurangnya kemampuan subjek dalam melakukan kontrol diri. Selain itu, adanya perasaan tidak aman membuat subjek cenderung ragu-ragu dalam mengambil keputusan, sehingga subjek membutuhkan banyak dorongan dari lingkungan eksternal. Meskipun demikian, adanya kemampuan introspeksi diri yang kuat dalam diri subjek dan motivasi untuk melakukan perubahan, dapat mendukung upaya subjek dalam mengontrol dirinya.

Data lain yang menunjukkan bahwa subjek memiliki beberapa masalah yang berkaitan dengan kecanduan pornografi, yang ditunjukkan oleh hasil cyber pornography addiction test (CYPAT) dengan jumlah skor sebesar 45 dari skor total sebesar 55. Kecanduan pornografi internet biasanya ditunjukkan dengan aktivitas menonton, mengunduh, dan memperdagangkan pornografi secara online atau keterlibatan dalam permainan peran orang dewasa (Spenhoff et al., 2013). Aktivitas yang dilakukan subjek hanya sebatas pada menonton yang berakibat pada penurunan produktivitas kesehariannya dan menghambat kehidupan sosial subjek. Meskipun awalnya subjek merasakan kepuasan dan kenyamanan tertentu, namun ia merasa banyak dirugikan dari perilaku tersebut, sehingga ia ingin mengurangi bahkan menghilangkan perilaku tersebut.

Penggunaan pornografi internet dan kecanduan yang dirasakan terhadap pornografi internet dikaitkan dengan berbagai indikator tekanan psikologis (Grubbs et al., 2014). Perilaku menonton film dewasa beradegan porno di internet yang terjadi pada subjek memunculkan konsekuensi tertentu yang membuat subjek cenderung mengulang perilaku tersebut ketika berada di situasi pemicu perilaku muncul. Hal ini dapat dijelaskan menggunakan teori operant conditioning milik salah satu tokoh behavioral yaitu B.F. Skinner tentang konsep A-B-C yang membuat perilaku bermasalah bertahan dalam diri subjek. Dengan begitu, perlu dilakukan penanganan dengan melakukan intervensi menggunakan modifikasi perilaku dengan menggunakan teknik self-control yang bertujuan untuk mengatur dan mengontrol diri subjek agar tidak melakukan perilaku maladaptif tersebut.

\section{Diagnosis dan Prognosis}

Subjek mengalami permasalahan berupa internet pornography addiction, yang ditunjukkan dengan perilaku menonton film dewasa beradegan porno di internet. Problem ini dianggap 
mengganggu karena sudah berdampak pada penurunan produktivitas dan menghambat kehidupan sosial subjek.

Prognosis baik karena adanya keinginan subjek untuk mengubah perilakunya dan ia berkomitmen untuk menjalankan proses intervensi dengan sebaiknya. Selain itu, subjek juga sebelumnya pernah melakukan usaha-usaha untuk mengurangi perilaku tersebut, sehingga terapis perlu untuk mengevaluasi dan memperkuat apa yang sudah dilakukan subjek.

\section{Intervensi}

Penanganan menggunakan modifikasi perilaku berupa self control yang dilakukan dengan cara mengajarkan keterampilan pada subjek dalam mengontrol dirinya ketika muncul keinginan untuk menonton film dewasa di internet. Self control dilakukan dengan menjalankan program-program tertentu, seperti manajemen waktu dan self talk. Manajemen waktu diartikan sebagai suatu cara yang dapat membantu individu dalam merencanakan, mengatur, dan menjadwalkan kegiatan dengan cara yang benar. Subjek perlu menggunakan manajemen waktu untuk mengontrol setiap aktivitas-aktivitas yang produktif dilakukan setiap harinya. Hal tersebut juga tentunya dilakukan agar subjek terhindar dari aktivitas yang dapat merugikan seperti menonton film dewasa di internet.

Seligman dan Reichenberg mendeskripsikan bahwa self talk merupakan pembicaraan positif yang diberikan seseorang kepada dirinya sendiri, dimana pembicaraan tersebut dimaksudkan untuk membangkitkan keberanian atau antusiasme individu yang melakukannya (Erford, 2015). Dengan menggunakan self talk untuk mengubah cara berpikir, subjek dapat mencapai kontrol yang lebih besar atas berbagai situasi. Oleh karena itu, penting untuk subjek dalam menggunakan self talk agar memperkuat motivasi subjek untuk mencapai target perubahan yang diinginkan. Program-program tersebut tentunya sudah disesuaikan dengan kebutuhan dan kondisi subjek apakah memungkinkan untuk menjalankan program tersebut selama proses intervensi berlangsung. Adapun rancangan kegiatan pada setiap sesi dan disertai dengan penjelasannya sebagai berikut.

Sesi 1: Spesifikasi masalah/problem dan menetapkan tujuan. Pada sesi ini, terapis mengajak subjek untuk berdiskusi tentang permasalahan yang dialami berdasarkan hasil wawancara yang dilakukan sebelumnya, kemudian dilanjutkan dengan penentuan spesifikasi masalah yang ingin segera ditangani oleh subjek. Terapis juga menjelaskan dinamika yang terjadi pada diri subjek sehingga perilaku maladaptif yang dialami subjek masih bertahan. Selanjutnya, terapis mengajak subjek untuk menentukan target perilaku yang ingin diubah pada dirinya.

Subjek mendengarkan dengan baik penjelasan yang diberikan oleh terapis dan ia pun menunjukkan sikap yang terbuka terhadap informasi-informasi yang ada. Subjek bersama terapis menyetujui bahwa perilaku maladaptif yang dialami subjek disebabkan oleh beberapa situasi pemicu yaitu ketika sedang sendiri, banyaknya waktu luang subjek setiap hari, dan lain-lain. Hal tersebut memicu terjadinya perilaku maladaptif yang memunculkan konsekuensi tertentu dan mendorong subjek untuk terus melakukannya. Adapun target yang ditentukan subjek dalam melakukan intervensi adalah menghilangkan perilaku maladaptif beruapa menonton film dewasa di internet.

Sesi 2: Membuat komitmen untuk berubah. Terapis mengajak subjek untuk memperkuat komitmennya dalam mengubah perilakunya, hal ini dilakukan untuk mempersiapkan subjek pada kondisi yang mungkin akan membuatnya tidak nyaman karena adanya perubahan aktivitas yang akan dilakukannya. Terapis meminta subjek untuk membuat list keuntungan yang didapatkan jika perilaku diubah dan kerugian jika perilaku tetap dipertahankan yang kemudian dievaluasi oleh terapis. Selanjutnya, terapis menjelaskan prosedur intervensi yang akan dilakukan oleh subjek dan memastikan kesediaan subjek dalam menjalankan setiap sesi yang direncanakan. 
Subjek memiliki keinginan yang kuat dalam menghilangkan perilaku maladaptif yang dialami dan akan menerima konsekuensi-konsekuensi yang akan didapatkan. Subjek pun menuliskan list keuntungan dan kerugian yang didapatkan untuk membangun komitmennya, ia menulis di kertas yang sudah disediakan oleh terapis. Salah satu keuntungan jika perilaku diubah yang dituliskan subjek adalah dapat memaksimalkan waktu dengan baik dengan melakukan hal-hal positif, kemudian salah satu kerugian jika perilaku tetap dipertahankan yaitu tidak konsentrasi dalam melakukan aktivitas. Subjek juga bersedia untuk melakukan proses intervensi yang direncanakan bersama terapis.

Sesi 3: Implementasi program 1. Pada sesi ini, terapis mengajarkan kepada subjek salah satu program yang perlu dilakukan yaitu manajemen waktu. Sebelumnya, terapis dan subjek telah melakukan identifikasi terkait situasi pemicu yang dapat memunculkan perilaku maladaptif berupa menonton film dewasa di internet. Sehingga, subjek perlu melakukan manajemen waktu dengan membuat list aktivitas yang harus dilakukan setiap hari, hal tersebut dilakukan agar subjek dapat mengontrol situasi pemicu yang menyebabkan terjadinya perilaku maladaptif. Selanjutnya, terapis meminta subjek untuk menerapkannya selama beberapa hari ke depan.

Subjek mengakui bahwa dirinya pernah melakukan hal yang sama dengan menuliskan aktivitas hariannya, namun hal tersebut dilakukan tidak didasarkan pada penghindaran situasi pemicu munculnya perilaku maladaptif sesuai dengan yang direncanakan bersama terapis. Sehingga subjek tidak merasakan adanya perubahan dalam dirinya. Dengan begitu, akan lebih mudah bagi subjek untuk melakukan manajemen waktu karena sebelumnya subjek pernah melakukan cara tersebut. Subjek pun bersedia untuk menerapkan cara tersebut untuk beberapa hari ke depan.

Sesi 4: Evaluasi. Terapis melakukan evaluasi dengan cara memeriksa lembaran aktivitas harian yang dilakukan subjek selama beberapa hari terakhir. Terapis juga melihat efektivitas program yang sudah diterapkan oleh subjek dengan meminta subjek untuk menilai efek yang dirasakan setelah menjalankan program tersebut. Selanjutnya, terapis meminta subjek untuk menceritakan kesulitan yang dialami dalam menerapkan program manajemen waktu.

Subjek menunjukkan kepada terapis lembaran aktivitas yang sudah dilakukan selama beberapa hari terakhir. Aktivitas-aktivitas yang direncanakan dan dilakukan subjek sangat positif seperti memperbanyak waktu untuk mendalami ilmu agama, melakukan kegiatan sosial, dan tentunya melakukan pekerjaannya. Subjek merasa bahwa cara tersebut memiliki efek yang cukup kuat dalam membuat subjek menghindari perilaku menonton film dewasa di internet. Namun, kesulitan yang dirasakan adalah ketika aktivitas-aktivitas yang sudah direncanakan tidak dapat dilakukan sesuai seperti yang dijadwalkan karena adanya perubahan aktivitas secara mendadak.

Sesi 5: Implementasi program 2. Pada sesi ini, terapis menjelaskan kepada subjek tentang program baru yang perlu dilakukan subjek untuk memperkuat teknik sebelumnya. Program yang dimaksudkan adalah self talk, dimana subjek diajarkan untuk membuat pembicaraan-pembicaraan pada diri sendiri yang nantinya bisa digunakan untuk memperkuat motivasi subjek untuk mencapai target perubahan yang diinginkan. Selanjutnya, terapis meminta subjek untuk membuat daftar self talk yang akan diterapkan dan bisa memberikan pengaruh pada komitmennya dalam mengubah perilakunya. Terapis meminta subjek untuk menerapkan self talk yang telah dibuat selama beberapa hari ke depan.

Subjek memahami hal-hal apa saja yang perlu dilakukan dalam sesi ini dan bersemangat untuk melakukannya. Subjek membuat daftar self talk yang akan ia terapkan dengan menuliskannya di lembaran yang sudah disediakan oleh terapis. Terdapat beberapa daftar self talk yang dibuat subjek cukup panjang, sehingga mungkin akan sulit bagi subjek untuk menghafalkannya. Namun, subjek mengakui bahwa kalimat tersebut memiliki pengaruh bagi 
dirinya. Pada akhir sesi, subjek juga bersedia untuk menerapkan program tersebut untuk memperkuat pelaksanaan manajemen waktu yang sudah dilakukan sebelumnya.

Sesi 6: Evaluasi dan mencegah relapse. Terapis melakukan evaluasi dan pemberian feedback terkait apa yang telah dilakukan subjek secara keseluruhan yaitu dalam pelaksanaan manajemen waktu dan self talk. Terapis memaparkan hal-hal yang perlu dilakukan subjek agar tidak relapse lagi yaitu dengan cara mengingatkan subjek untuk menghindari situasi-situasi yang menjadi pemicu munculnya perilaku menonton film dewasa di internet dan menghindari self talk yang tidak produktif seperti berkata "tidak apa-apa dicoba sekali." Terapis juga meminta subjek untuk mencoba menemukan aktivitas-aktivitas produktif yang berdasarkan hobby atau skill yang pernah dimiliki sebelumnya.

Subjek mengungkapkan bahwa beberapa cara yang dilakukan selama intervensi memberikan efek yang cukup kuat dalam membantunya menghindar dari perilaku maladaptif berupa menonton film dewasa di internet. Meskipun, terkadang dorongan bahkan perilaku menonton sempat dilakukan subjek ketika dalam proses pelaksanaan intervensi. Subjek memiliki rencana untuk melakukan aktivitas baru seperti yaitu memelihara ikan dan membaca buku-buku yang menceritakan tentang kisah-kisah nabi dan sejarah islam.

Sesi 7: Terminasi. Pada sesi ini, terapis mendiskusikan perubahan perasaan dan perilaku yang dialami subjek selama proses intervensi. Terapis juga memberikan apresiasi terhadap pencapaian perubahan yang telah mampu dilakukan subjek dan memotivasi subjek agar tetap konsisten dalam menerapkan program yang sudah dilakukan selama proses intervensi, serta mengakhir program intervensi.

Subjek mengungkapkan bahwa dirinya telah mampu mengontrol situasi yang dapat memicu munculnya perilaku menonton film dewasa di internet. Ia juga merasa lebih lega dan senang dengan perubahan yang dirasakan. Subjek juga sudah merencanakan beberapa aktivitas baru yang akan dia lakukan dan ia pun bersemangat untuk melakukannya.

Sesi 8: Follow up. Terapis melakukan evaluasi terkait perubahan perilaku subjek dalam jangka waktu 1 minggu pasca intervensi dengan menanyakan tentang intensitas dan frekuensi perilaku maladaptif, aktivitas keseharian yang dilakukan subjek, dan pelaksanaan aktivitas baru yang direncanakan sebelumnya.

Subjek melaporkan bahwa ia melakukan perilaku menonton film dewasa sebanyak 1 kali, hal tersebut terjadi karena saat itu ia tidak melakukan aktivitas seperti biasanya dikarenakan kondisi sakit. Namun, setelahnya ia berusaha mengingatkan dan mengendalikan dirinya kembali. Aktivitas baru yang dilakukan subjek adalah mulai memelihara ikan, membaca buku, menjalin komunikasi kembali dengan teman-teman lamanya dan berencana untuk membuat usaha dengan temannya.

\section{Hasil dan Pembahasan}

\section{Hasil}

Hasil perbandingan sebelum dan sesudah dilakukannya intervensi dievaluasi berdasarkan capaian subjek dalam pencapaian target perilaku yang telah disepakati sebelumnya. Subjek menginginkan bahwa dirinya bisa untuk mengurangi bahkan menghilangkan perilaku maladaptifnya berupa menonton film dewasa di internet. Terapis juga melakukan pengukuran menggunakan cyber pornography addiction test untuk melihat tingkat permasalahan yang dialami subjek terkait dengan kecanduan pornografi. Pada Gambar 1 terlihat hasil sebelum dan sesudah pemberian intervensi.

Gambar 1 menunjukkan bahwa adanya penurunan tingkat permasalahan yang dialami subjek yang berkaitan dengan kecanduan pornografi. Sebelum intervensi, subjek mendapat skor 45 dengan kategori lebih dari nilai rata-rata yang berarti tingkat permasalahan cenderung 


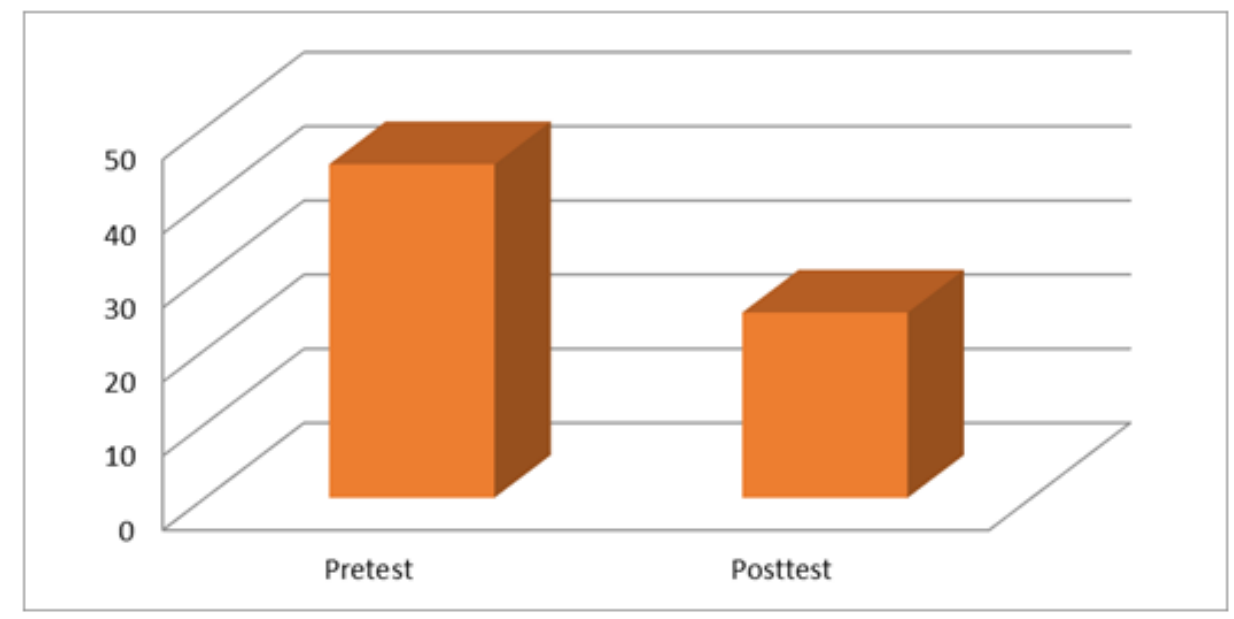

Gambar 1. Hasil pretest dan posttest instrumen CYPAT.

tinggi. Kemudian setelah intervensi, subjek mendapat skor 25 dengan kategori kurang dari nilai rata-rata yang berarti tingkat permasalahan cenderung rendah.

Sebelum intervensi, subjek sudah melakukan usaha-usaha agar dirinya bisa menghindari perilaku maladaptifnya. Namun, ia merasa gagal karena dorongan untuk menonton masih kuat dan hal yang dirasakan subjek ketika tidak menonton adalah gelisah. Intensitas perilaku menonton yang dilakukan subjek dalam waktu 2 minggu sebelum intervensi adalah 4-5 kali seminggu dengan frekuensi waktu yang dihabiskan sebanyak 3-4 jam. Di sisi lain, ia merasakan ketidaknyamanan dari perilakunya tersebut karena munculnya perasaan berdosa, aktivitas hariannya menjadi terhambat, produktivitas berkurang, karena setelah menonton film dewasa tersebut subjek menjadi malas untuk melakukan aktivitas selanjutnya. Tabel 1 menggambarkan capaian perubahan perilaku subjek.

Tabel 1. Hasil Capaian Perubahan Perilaku

\begin{tabular}{llll}
\hline Perkembangan & Intensitas & Frekuensi & Total \\
\hline Pra-terapi & $5 \mathrm{x} /$ minggu & $3-4$ jam & $5 \mathrm{x}$ \\
Terapi & $0 / 5$ hari & 0 & 0 \\
& $2 \mathrm{x} / 5$ hari & $1-2$ jam & $2 \mathrm{x}$ \\
& $0 / 5$ hari & 0 & 0 \\
Pascaterapi & $1 \mathrm{x} /$ minggu & 1 jam & $1 \mathrm{x}$ \\
\hline
\end{tabular}

Setelah intervensi, perilaku menonton film dewasa beradegan porno di internet mulai berkurang. Subjek masih melakukannya dengan intensitas dan frekuensi yang lebih sedikit dibandingkan dengan sebelumnya yaitu $1 \mathrm{x}$ dalam jangka waktu 1 jam. Hal tersebut bisa terjadi karena subjek berhasil untuk mengontrol dirinya dengan mengatur waktunya untuk melakukan aktivitas-aktivitas yang lebih positif. Ia mencoba menghindari situasi-situasi yang bisa memunculkan dorongan untuk menonton, yaitu tidak menyendiri dan mengurangi waktu luang.

Subjek juga melakukan penghindaran situasi pemicu dengan cara mencari kesibukan di luar rumah, yaitu selain bekerja ia juga mulai aktif untuk mengikuti taklim dan kegiatan-kegiatan sosial. Kegiatan tersebut tentunya memiliki efek bagi subjek dalam mengurangi perilaku maladaptifnya, meskipun terkadang masih ada dorongan-dorongan tertentu yang ia alami. Namun, subjek tidak menyalurkan dorongan untuk menonton tersebut. Subjek saat ini juga 
mulai lebih lega dan tenang dengan perubahan yang dirasakan didukung dengan aktivitas yang dilakukannya sekarang.

Pencapaian yang didapatkan subjek juga dipengaruhi oleh aktivitas penggunaan handphone yang mulai dibatasi oleh subjek, ia mengatur waktu dan mengontrol dirinya agar tidak terlibat dalam perilaku menonton film dewasa di internet. Selain itu, adanya ketertarikan subjek terhadap hal-hal baru membuat subjek menemukan aktivitas baru untuk mengalihkan perilaku maladaptifnya. Aktivitas yang dilakukan tersebut berupa membaca sesuatu yang belum pernah ia ketahui sebelumnya, seperti buku-buku yang menceritakan tentang kisah-kisah nabi dan sejarah islam. Selain itu, subjek juga mencoba mencari aktivitas baru berupa memelihara ikan sebagai bentuk penyaluran terhadap hobi dan kemampuan yang pernah dimiliki.

\section{Pembahasan}

Dalam pelaksanaan terapi, terapis melihat motivasi dan komitmen subjek dalam mengubah perilakunya sangatlah kuat. Hal ini juga dikarenakan sebelumnya subjek sudah melakukan usaha-usaha tertentu, sehingga terapis perlu mengevaluasi dan mengajarkan keterampilan baru dalam mengontrol perilakunya tersebut. Dalam hal ini, faktor internal berperan penting dalam perubahan perilaku, yaitu peningkatan kompetensi, kesabaran, dan kemauan untuk bertahan dengan perubahan perilaku yang terjadi. Subjek telah menggunakan sumber daya pribadinya untuk tetap termotivasi dalam mencapai target perilaku yang diinginkannya.

Strategi lain yang bisa digunakan adalah melakukan penghindaran terhadap situasi-situasi yang dapat memicu munculnya dorongan bahkan perilaku yang ingin diubah. Dalam hal ini, subjek melakukan penghindaran terhadap situasi yang memunculkan keinginannya untuk menonton film dewasa di internet. Subjek juga mengatur dirinya untuk mengurangi penggunaan smartphone dan hanya digunakan ketika diperlukan. Hal tersebut dinamakan dengan teknik manajemen lingkungan yang membantu subjek untuk mengontrol dirinya agar dapat mengurangi bahkan menghilangkan perilaku maladaptifnya.

Hal-hal yang telah dilakukan subjek juga didukung oleh beberapa hasil penelitian bahwa beberapa cara pengalihan yang bisa dilakukan untuk menghindari penggunaan internet yang berlebihan dan bermasalah (termasuk menonton pornografi) adalah dengan mengalihkan perhatian terhadap minat atau aktivitas lain, fokus pada kegiatan yang menyenangkan dan mendukung kreativitas (misalnya: hobi), meningkatkan produktivitas dalam pekerjaan, hubungan sosial, atau kebugaran fisik (Rodda, Booth, Vacaru, Knaebe, \& Hodgins, 2018).

Dengan adanya hal-hal yang dapat memperkuat perubahan perilaku subjek membuatnya lebih mudah dalam pencapaian perilaku yang diinginkan. Hal tersebut adalah dukungan sosial, spiritualitas, dan kesejahteraan (Rodda et al., 2018). Dukungan sosial berupa penilaian yang diperoleh dari orang lain tentang perilakunya yang maladaptif membuat subjek menjadi yakin dan termotivasi untuk mengubah perilakunya. Spiritualitas menjadi penguat dari sisi nilai dan hukum yang mengatur perilaku maladaptif yang dilakukan subjek, yang diperoleh subjek dari majelis ilmu yang ia ikuti. Serta kesejahteraan yang dirasakan ketika mulai menjauh dari perilaku menonton film dewasa beradegan porno di internet membuat subjek mampu untuk menjaga komitmen dan mencegah terjadinya kekambuhan.

Saat ini, subjek telah mampu untuk mengontrol situasi-situasi pemicu untuk menonton film dewasa beradegan porno. Subjek mencari kesibukan lain selain yang biasa dilakukannya, seperti menjalin komunikasi kembali dengan teman-teman lamanya, berbincang dengan temannya dan berencana untuk membuat usaha sendiri untuk lebih memperbanyak kegiatan positif. Selain itu, subjek juga melakukan introspeksi dan mengingat kembali potensi-potensi yang pernah ia miliki dengan mengikuti berbagai pelatihan untuk meningkatkan keterampilan. Dengan begitu, subjek bisa melakukan berbagai hal dan tidak lagi mengeluhkan tentang dirinya yang memiliki banyak waktu luang dan jenuh dengan aktivitas kesehariannya. 


\section{Simpulan}

Modifikasi perilaku menggunakan teknik self-control memiliki pengaruh untuk mengurangi perilaku maladaptif berupa menonton film dewasa beradegan porno di internet yang dialami subjek. Dalam hal ini, tentunya motivasi internal untuk menjalankan program-program dalam intervensi harus dijaga oleh subjek. Selain itu, adanya penguatan terhadap komitmen juga diperlukan agar subjek bisa menahan godaan terhadap stimulus yang mendorongnya untuk melakukan perilaku maladaptif yang ingin diubah oleh subjek.

\section{Referensi}

Block, J. J. (2008). Issues for DSM-V: Internet addiction. The American Journal of Psychiatry, 165(3), 306-307. https://doi.org/10.1176/appi.ajp.2007.07101556

Cacioppo, M., Gori, A., Schimmenti, A., Baiocco, R., Laghi, F., \& Caretti, V. (2018). Development of a new screening tool for cyber pornography: Psychometric properties of the cyber pornography addiction test (CYAPT). Clinical Neuropsychiatry, 15(1), 3-8.

Erford, B.T., (2015). 40 Teknik yang harus diketahui setiap konselor edisi kedua. Yogyakarta: Pustaka Belajar.

Grubbs, J. B., Volk, F., Exline, J. J., \& Kenneth, I. (2014). Internet pornography use: Perceived addiction, psychological distress, and the validation of a brief measure. Journal of Sex \& Marital Therapy, 0, 1-24. https://doi.org/10.1080/0092623X.2013.842192

Kraus, S. W., Martino, S., \& Potenza, M. N. (2016). Clinical characteristics of men interested in seeking treatment for use of pornography. Journal of Behavioral Addictions, 5(2), 169-178. https://doi.org/10.1556/2006.5.2016.036

Kraus, S. W., Rosenberg, H., Martino, S., Nich, C., \& Potenza, M. N. (2017). The development and initial evaluation of the pornography-use avoidance self-efficacy scale. Journal of Behavioral Addictions, 6(3), 354-363. https://doi.org/10.1556/2006.6.2017.057

Rodda, S. N., Booth, N., Vacaru, M., Knaebe, B., \& Hodgins, D. C. (2018). Behaviour change strategies for internet, pornography and gaming addiction: A taxonomy and content analysis of professional and consumer websites. Computers in Human Behavior, 84, 467-476. https://doi.org/10.1016/j.chb.2018.03.021

Spenhoff, M., Kruger, T. H. C., Hartmann, U., \& Kobs, J. (2013). Hypersexual behavior in an online sample of males: Associations with personal distress and functional impairment. International Society for Sexual Medicine, 10, 2996-3005. https://doi.org/10.1111/jsm.12160 